\title{
Diatom communities in thermo-mineral springs of Galicia (NW Spain)
}

\author{
Manel Leira ${ }^{1}$, Rosa Meijide-Failde ${ }^{2} \&$ Enrique Torres $^{3}$ \\ ${ }^{1}$ Laboratório Associado IDL, Faculdade de Ciencias, Universidade de Lisboa, Lisboa, Portugal \\ ${ }^{2}$ Grupo de Terapia Celular y Medicina Regenerativa, Instituto de Investigación Biomédica de A Coruña \\ (INIBIC), Complexo Hospitalario Universitario de A Coruña (CHUAC), Sergas, Universidade da Coruña \\ (UDC), A Coruña, Spain \\ ${ }^{3}$ Laboratorio de Microbiología, Facultad de Ciencias, Universidade da Coruña, A Coruña, Spain
}

\begin{abstract}
The species composition of diatom assemblages was studied in five unpolluted thermo-mineral springs in Galicia (NW Spain). Three are considered hot and two cold, and some contain hydrogen sulphide. A total of 68 taxa (24 genera) have been recorded. The Shannon-Wiener diversity index $\left(H^{\prime}\right)$ ranged between 0.63 and 2.01. The nMDS ordination showed that diatom assemblage composition was influenced mostly by conductivity, temperature and hydrogen sulphide concentration. Diatom assemblages found in the Galician springs differed from those in springs of other geographical locations with similar physical and chemical characteristics. The most species-rich genera were Nitzschia and Achnanthidium with 10 and 8 species, respectively. Achnanthidium exiguum and Achnanthidium saprophilum had the widest distribution. Denticula thermalis and Achnanthidium caledonicum were found in environments with relatively low mineralization and low temperature, whereas Rhopalodia gibberula, Rhopalodia operculata and Fragilaria crotonensis were found in mineral-rich springs with high temperatures. Achnanthidium exiguum, A. saprophilum, Achnanthes coarctata, Achnanthes exigua var. elliptica, Mayamaea atomus, Eunotia implicata, Gomphonema minusculum, Gomphonema minutum and Cosmioneis pusilla were present in the spring with high $\mathrm{H}_{2} \mathrm{~S}$ content.
\end{abstract}

Keywords:

Biodiversity, Diatoms, Environmental parameters, Galicia, Thermo-mineral springs, Thermal-sulphur waters 


\section{Introduction}

The outstanding importance of springs for the conservation of freshwater biodiversity is increasingly being recognized (Cantonati et al. 2012). Since they originate underground, most permanent freshwater springs have fairly stable physical and chemical characteristics. Due to this, and despite their small size, springs have great ecological value. They are very interesting ecotones for studies of biological communities because their biota is often enriched by rare taxa and endemics, which from a biogeographic point of view can be very important (Kilroy et al. 2007). For these reasons, springs are unique aquatic habitats for the study of microalgal floras, especially diatoms, which are often dominant. In addition, the particular conditions that occur in some springs make them ideal places to study specific algal assemblages in extreme natural conditions, such as high temperature, low $\mathrm{pH}$ and the presence of hydrogen sulphide (Hambrook et al. 1999, Denicola 2000, Quintela et al. 2013).

Galicia (NW Spain) is an area with extensive thermo-mineral groundwater resources, many of them with therapeutic value, constituting an important resource for human utilization. More than 300 springs are registered in Galicia, of which 22 have been used for therapeutic purposes since ancient times (Roman thermal baths) (Xunta de Galicia 1995). The regional geologic diversity ensures high variability in the hydrochemical facies of its mineral waters, and for this reason many different spring types are found, including the commoner, cold and moderately mineralized, thermal or saline springs. In addition, one characteristic of this area is the presence of many sulphur springs that are formed where deep waters rise through igneous and metamorphic rocks of high sulphide content, where conditions can be anoxic. Many of these springs are also unpolluted by nutrients.

However, despite the importance and usefulness of these environments, the biota of the thermo-mineral springs in Galicia has been little studied (Noguerol 1984), especially in relation to diatoms. For this reason, the main objective of this work was to describe the current taxonomic composition and structure of the epilithic diatom assemblages in certain springs in Galicia, determining the relationships between their environmental variables and their species composition.

\section{Methods}

\section{Location and description of the sampled springs}

Five springs in Galicia (NW Spain) were selected for this study. Galicia is located in the socalled wet Iberia with an oceanic climate. Its main features are the regularity of rainfall during the year, from 1000 to $1500 \mathrm{~mm}$ per year and mild temperatures with low annual oscillation. The selected springs are representative of the broader range of springs that can be found within the Hesperian massif. In addition, they are considered unchanged since ancient times and are currently used for balneotherapy. Three thermal springs, As Burgas $\left(42^{\circ} 20^{\prime} 04^{\prime \prime} \mathrm{N}, 7^{\circ} 51^{\prime} 55^{\prime \prime} \mathrm{W}\right)$, Outariz $\left(42^{\circ} 20^{\prime \prime} 56^{\prime \prime} \mathrm{N}, 7^{\circ} 54^{\prime} 58^{\prime \prime} \mathrm{W}\right)$ and Cuntis $\left(42^{\circ} 38^{\prime} 10^{\prime \prime} \mathrm{N}, 8^{\circ} 33^{\prime} 45^{\prime \prime} \mathrm{W}\right)$, and two cold-water springs,

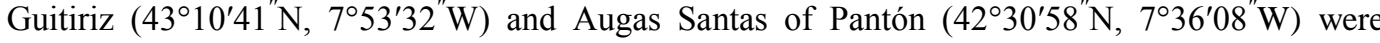
studied (Fig. 1). Three of these springs (Cuntis, Pantón and Guitiriz) are considered sulphur springs. 


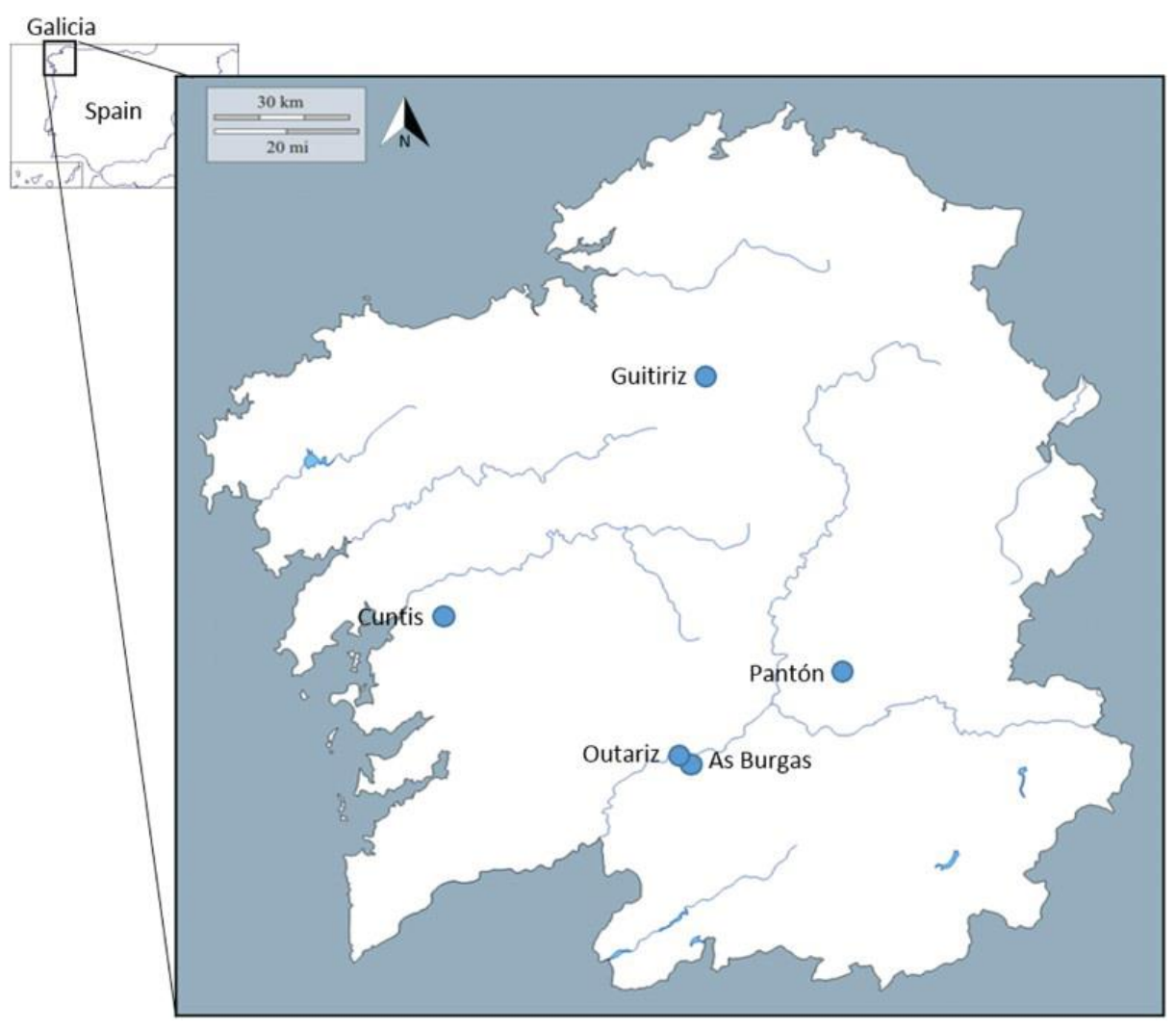

Fig. 1. Maps showing the geographical locations of the five springs selected for the present work.

The As Burgas and Outariz springs are characterized by high temperature (60-65 and 56$62^{\circ} \mathrm{C}$, respectively) and are located in the city of Ourense, at the bottom of a valley excavated by the Miño River. Both springs arise through a dense network of fissures (Delgado-Outeiriño et al. 2009). Lithologically, they are situated on granite crystalline rocks covered by alluvial soils and their waters emerge at the highest temperature of all the thermal springs in Galicia. With a flow rate of $50 \mathrm{~L} \mathrm{~s}^{-1}$, As Burgas flows through a nineteenth century granite building, comprising a niche with a central pillar that sits in a $7 \mathrm{~cm}$ deep basin. This basin receives the water that overflows from the upper $1 \mathrm{~cm}$ deep basin. Some of the water that overflows from the lower basin runs through a narrow channel where the water accumulates. The samples from this spring were taken by scraping the surface of the granite stones (Fig. 2). The Outariz spring emerges directly among rocks at the margin of the Miño River with a flow rate of $10 \mathrm{~L} \mathrm{~s}^{-1}$, running through the rocks down to the river. The samples were taken from the rock surfaces (Fig. 3). 

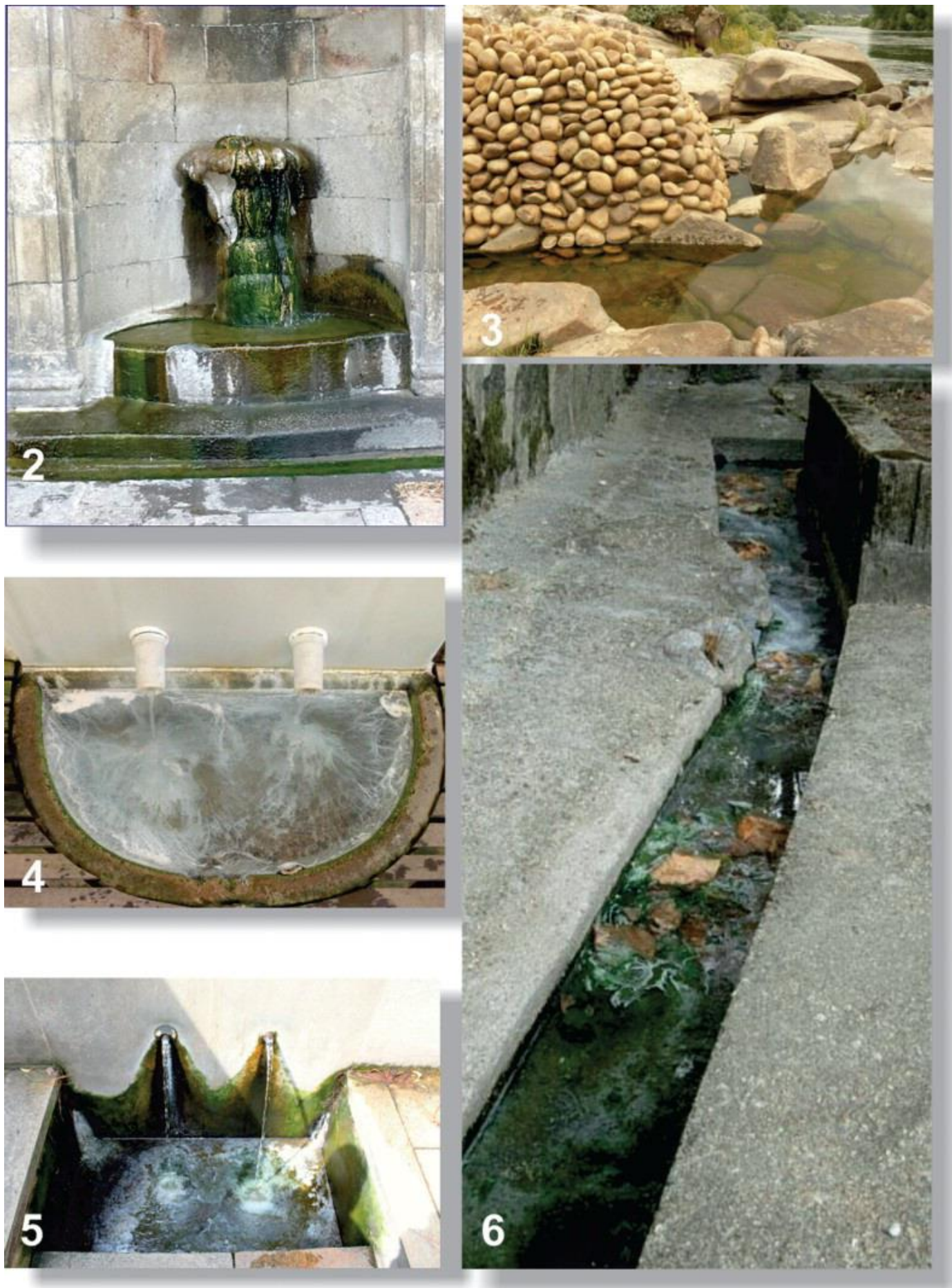

Figs 2-6. Photographs illustrating the morphology of the springs and the sampling sites. Fig. 2. As Burgas. Fig. 3. Outariz. Fig. 4. Guitiriz. Fig. 5. Aguas Santas of Pantón. Fig. 6. Cuntis. 
Guitiriz and Augas Santas of Pantón springs are considered cold (14-17 and 19-20 ${ }^{\circ}$, respectively) and are located in the Ollo de Sapo domain where there is great rock diversity, in addition to the dominant granite massifs (Corral \& López 2010). Guitiriz comprises an artificial stone fountain with a semi-circular basin fed by water from two pipes. The basin is about $90 \mathrm{~cm}$ long, 50 wide and 20 deep, and excess water drains into an underground sink. The flow rate is 0.5 $\mathrm{L} \mathrm{s}^{-1}$. Samples were taken from the walls of the fountain (Fig. 4). The Aguas Santas of Pantón spring emerges directly from the rocks with a flow rate of $1.5 \mathrm{~L} \mathrm{~s}^{-1}$. Its waters are collected in a rectangular basin through two pipes. The water drains continuously through a hole in the bottom of the basin. Samples were taken from the walls of this basin (Fig. 5).

The Cuntis spring experiences deep hydrothermal flows and intermediate chemical evolution passing through granites and biotitic granodiorites, and its water is considered warm to hot (48$54^{\circ} \mathrm{C}$ ). Samples from this spring were collected from a granite channel, $20 \mathrm{~cm}$ wide, $15 \mathrm{~cm}$ deep and $8 \mathrm{~m}$ long, through which water flows continuously at $0.6 \mathrm{~L} \mathrm{~s}^{-1}$. The thermal water of this spring emerges inside a nearby building, passing through a hole in the wall (Fig. 6).

\section{Physical and chemical characteristics}

Water temperature, $\mathrm{pH}$ and conductivity were measured in situ at four different points in each spring, as close as possible to the diatom sampling sites, with portable instruments calibrated in the field. Temperature and $\mathrm{pH}$ were measured with an HI 8014 Crison-Hanna meter and conductivity was measured using an $\mathrm{HI} 8633$ probe EC meter. Water samples were collected in $1 \mathrm{~L}$ polyethylene bottles to allow major ions, nutrients and trace elements to be analysed in the laboratory following standard procedures and methods (Apha 2005).

\section{Sampling and identification of diatoms}

The algae were scraped off the stones, edges and bottom of the springs with a sterile knife, according to European recommendations (Kelly et al. 1998). Four samples were collected from each spring. The samples were immediately preserved with formalin (4\% final concentration) and stored in plastic tubes. The samples were cleaned of organic matter following standard methods (Comité European de Normalisation 2003). Permanent diatom slides were made with Naphrax®. Diatoms were examined using a light microscope (LM) (Olympus BX51) with a $\times 100$ oil immersion DIC objective. Approximately, 400 valves were counted in each sample. Light photographs of the most abundant taxa were taken with a DP70 Olympus camera. Diatoms were identified using standard floras and related literature (Krammer \& Lange-Bertalot 1986, 1988, 1991a, 1991b, 2000, Lange-Bertalot 1993, 1999, Potapova \& Hamilton 2007, Hofmann et al. 2013, Trobajo et al. 2013).

\section{Data and statistical analysis}

For the numerical analyses, diatom count data were expressed as relative abundances. Species diversity was calculated using the Shannon-Wiener diversity index $\left(H^{\prime}\right)$ (Shannon \& Weaver 1963). A non-metric multidimensional scaling technique (nMDS) with Bray-Curtis distance measure, 100 maximum iterations and square-root transformation of diatom data was used to explore variation of diatom assemblages in the studied springs. Environmental variables were correlated to the nMDS axes using environmental vector fitting (envfit procedure). Environmental variables were first transformed using square-root transformation and standardized. Redundant environmental variables were eliminated taking into account those that obtained a value greater than 0.78 in a Pearson correlation matrix. With the variables retained in the analysis, the fit $\left(R^{2}\right)$ of each variable to the ordination using the envfit function (see below) was assessed with a MonteCarlo analysis of 999 permutations. nMDS and correlation with environmental variables (envfit 
function) were performed using the BiodiversityR library (Kindt \& Coe 2005) in the R programming environment v. 3.3.1 (R Core Team 2016).

\section{Results}

\section{Environmental parameters}

There was great variability in temperature and conductivity (Table 1), but $\mathrm{pH}$ did not vary much and was always above 7.0 in all the springs (weak alkaline or alkaline springs). Carbonate and bicarbonate were the prevalent anions in most of the springs. The Pantón, Cuntis and, to a lesser extent, Guitiriz samples had higher proportions of sulphate. The percentage of $\mathrm{Na}$ and $\mathrm{K}$ ions was high in all samples, unlike $\mathrm{Ca}$ and $\mathrm{Mg}$ ions which were very low in all springs. $\mathrm{SiO}_{2}$ was also high, especially in Cuntis and As Burgas.

Table 1. Range of the physical and chemical characteristics obtained at the sampling points $(n=4)$ in the five springs.

\begin{tabular}{|c|c|c|c|c|c|}
\hline Parameter/Spring & Cuntis & Pantón & Guitiriz & As Burgas & Outariz \\
\hline Temperature $\left({ }^{\circ} \mathrm{C}\right)$ & $40-43$ & $19-20$ & $13-17$ & $37-42$ & $40-44$ \\
\hline $\mathrm{pH}$ & $8.7-8.9$ & $7.9-9.0$ & $8.4-9.5$ & $7.5-7.8$ & $7.2-7.8$ \\
\hline Conductivity $\left(\mu \mathrm{S} \mathrm{cm}^{-1}\right)$ & $487-526$ & $674-689$ & $340-354$ & $835-864$ & $556-580$ \\
\hline $\mathrm{F}^{-}\left(\mathrm{mg} \mathrm{L}^{-1}\right)$ & $18-22$ & $20-29$ & $14-17$ & $12-14$ & $11-17$ \\
\hline $\mathrm{Cl}^{-}\left(\mathrm{mg} \mathrm{L}^{-1}\right)$ & $55-59$ & $39-58$ & $24-29$ & $18-24$ & $19-26$ \\
\hline $\mathrm{HCO}_{3}^{-}\left(\mathrm{mg} \mathrm{L}^{-1}\right)$ & $45-76$ & $180-232$ & $49-87$ & $512-646$ & $316-327$ \\
\hline $\mathrm{CO}_{3}{ }^{2-}\left(\mathrm{mg} \mathrm{L}^{-1}\right)$ & $22-94$ & $24-30$ & $<$ d.1.-6 & $<$ d.1. & $<$ d.1.-2 \\
\hline $\mathrm{SO}_{4}{ }^{2-}\left(\mathrm{mg} \mathrm{L}^{-1}\right)$ & $45-48$ & $64-85$ & $15-37$ & $3-11$ & $9-20$ \\
\hline $\mathrm{S}^{-2}\left(\mathrm{mg} \mathrm{L}^{-1}\right)$ & $21-37$ & $18-20$ & $11-66$ & $<$ d.1. & $<$ d.1. -1 \\
\hline $\mathrm{Li}^{+}\left(\mathrm{mg} \mathrm{L}^{-1}\right)$ & $0.1-1$ & $3-3.1$ & $0.5-0.8$ & $4-5$ & $0.8-1.2$ \\
\hline $\mathrm{Na}^{+}\left(\mathrm{mg} \mathrm{L}^{-1}\right)$ & 104-109 & $129-133$ & $68-83$ & $202-260$ & $136-142$ \\
\hline $\mathrm{K}^{+}\left(\mathrm{mg} \mathrm{L}^{-1}\right)$ & $3-4$ & $4.9-5.1$ & $0.8-1$ & $9-11$ & $5-5.3$ \\
\hline $\mathrm{Mg}^{2+}\left(\mathrm{mg} \mathrm{L}^{-1}\right)$ & $0.04-1$ & $2-3$ & $0.1-0.9$ & $1-3$ & $0.9-1$ \\
\hline $\mathrm{Ca}^{2+}\left(\mathrm{mg} \mathrm{L}^{-1}\right)$ & $1.8-3$ & $4-7$ & $1.2-4$ & $3-7$ & $2-7$ \\
\hline $\mathrm{Mn}^{2+}\left(\mathrm{mg} \mathrm{L}^{-1}\right)$ & $<\mathrm{d} .1$. & $<$ d.1.-0.012 & $<$ d.1. & 0.04 & 0.02 \\
\hline $\mathrm{NH}_{4}^{+}\left(\mathrm{mg} \mathrm{L}^{-1}\right)$ & $03-05$ & $4.4-5.4$ & 0.92 & $0.7-1.01$ & $0.39-055$ \\
\hline $\mathrm{SiO}_{2}\left(\mathrm{mg} \mathrm{L}^{-1}\right)$ & $89-95$ & $36-42$ & $18-26$ & $84-88$ & $61-92$ \\
\hline $\mathrm{Fe}^{2+}\left(\mu \mathrm{g} \mathrm{L}^{-1}\right)$ & $<$ d.1. -0.04 & $72-182$ & $<$ d.1. -0.33 & $35-53$ & $<$ d.1. -3 \\
\hline $\mathrm{Ba}^{2+}\left(\mu \mathrm{g} \mathrm{L}^{-1}\right)$ & $0.6-1$ & $6-6.2$ & $<$ d.l. & 44-94 & $0.1-2.3$ \\
\hline $\mathrm{Al}^{3+}\left(\mu \mathrm{g} \mathrm{L}^{-1}\right)$ & $7-19$ & $30-33$ & $<$ d.1. & $19-29$ & $<$ d.1.1.-12 \\
\hline $\mathrm{H}_{2} \mathrm{~S}\left(\mathrm{mg} \mathrm{L}^{-1}\right)$ & $7-8$ & $2.4-2.7$ & $1.3-1.5$ & $<$ d.1. & $<$ d.1. \\
\hline
\end{tabular}

Note: d.1. = detection limit. 
Table 2. Species composition and relative abundance of diatoms in the studied springs.

\begin{tabular}{|c|c|c|c|c|c|c|}
\hline Taxon name & Abbreviations & $\begin{array}{c}\text { As } \\
\text { Burgas }\end{array}$ & Cuntis & Guitiriz & Pantón & Outariz \\
\hline Achnanthes coarctata (Brébisson) Grunow & AchCo & 0 & $0-1$ & 0 & 0 & 0 \\
\hline Achnanthes exigua var. elliptica Hustedt & AchEx & $0-1$ & $0-1$ & 0 & 0 & 0 \\
\hline Achnanthidium caledonicum (Lange-Bertalot) Lange-Bertalot & AchCal & 0 & 0 & $1-3$ & 0 & 0 \\
\hline Achnanthidium exiguum (Grunow) Czarnecki & AchExi & $2-4$ & $3-5$ & $0-1$ & 0 & $0-1$ \\
\hline Achnanthidium exile (Kützing) Heiberg & AchExil & 0 & 0 & 0 & 0 & 1 \\
\hline Achnanthidium lanceolatum Brébisson ex Kützing & AchLan & 0 & $0-1$ & $0-1$ & 0 & $0-1$ \\
\hline Achnanthidium lineare W. Smith & AchLi & 0 & 0 & $0-1$ & $0-1$ & $0-1$ \\
\hline Achnanthidium minutissimum (Kützing) Czarnecki & AchMi & 1 & 0 & 0 & 1 & $1-2$ \\
\hline $\begin{array}{l}\text { Achnanthidium saprophilum (H. Kobayasi \& S. Mayama) } \\
\text { Round \& L. Bukhtiyarova }\end{array}$ & AchSa & $0-1$ & 1 & 0 & $1-3$ & $0-1$ \\
\hline Achnanthidium subhudsonis (Hustedt) H. Kobayasi & AchSub & 0 & 0 & 0 & 0 & $0-1$ \\
\hline Amphora pediculus (Kützing) Grunow ex A. Schmidt & $\mathrm{AmPe}$ & 0 & 0 & 0 & 0 & $0-1$ \\
\hline Caloneis vasileyevae Lange-Bertalot, Genkal \& Vekhov & CaVasi & 0 & $0-1$ & 0 & 0 & 0 \\
\hline Cocconeis placentula var. euglypta (Ehrenberg) Grunow & CocPla & $0-1$ & 0 & 0 & 0 & $0-1$ \\
\hline Cocconeis pseudolineata (Geitler) Lange-Bertalot & CocPsel & 0 & 0 & 0 & 0 & $0-1$ \\
\hline Cocconeis pseudothumensis Reichardt & CocPseth & $0-1$ & 0 & 0 & 0 & 0 \\
\hline Cosmioneis pusilla (W. Smith) D.G. Mann \& A.J. Stickle & $\mathrm{CosPu}$ & 0 & $0-1$ & 0 & 0 & 0 \\
\hline $\begin{array}{l}\text { Ctenophora pulchella (Ralfs ex Kützing) D.M.Williams \& } \\
\text { Round }\end{array}$ & CtePul & 0 & 0 & 0 & 0 & 1 \\
\hline Cyclotella meneghiniana Kützing & CyMen & 0 & 0 & 0 & 0 & $0-1$ \\
\hline Denticula thermalis Kützing & DenTher & 0 & 0 & $3-5$ & 0 & 0 \\
\hline Diadesmis contenta (Grunow) D.G. Mann & DiadCont & $0-1$ & $0-1$ & 0 & 0 & $0-1$ \\
\hline Diatoma mesodon (Ehrenberg) Kützing & DiatMes & 0 & 0 & 0 & 0 & $0-1$ \\
\hline Encyonema minutum (Hilse) D.G. Mann & EnMi & 0 & 0 & 0 & 0 & $0-1$ \\
\hline Encyonema silesiacum (Bleisch) D.G. Mann & EnSi & 0 & 0 & 0 & 0 & 1 \\
\hline Eolimna minima (Grunow) Lange-Bertalot \& W. Schiller & EoMi & 0 & $0-1$ & 0 & 0 & $0-1$ \\
\hline Eunotia implicata Nörpel, Lange-Bertalot \& Alles & EuImp & 0 & $0-1$ & 0 & 0 & 0 \\
\hline Fallacia vitrea (Østrup) D.G. Mann & $\mathrm{FaVi}$ & $0-1$ & 0 & 0 & 0 & $0-1$ \\
\hline Fragilaria acus (Kützing) Lange-Bertalot & FraAc & 0 & 0 & 0 & $0-2$ & $0-1$ \\
\hline Fragilaria crotonensis Kitton & FraCro & 0 & 0 & 0 & 0 & $2-4$ \\
\hline $\begin{array}{l}\text { Fragilaria pararumpens Lange-Bertalot, G. Hofmann \& } \\
\text { Werum }\end{array}$ & FraPar & 0 & 0 & 0 & 0 & $0-1$ \\
\hline Fragilaria perminuta (Grunow) Lange-Bertalot & FraPer & 0 & 0 & 0 & 0 & $0-1$ \\
\hline Fragilaria rumpens (Kützing) G.W.F. Carlson & FraRu & 0 & 0 & 0 & 0 & $0-1$ \\
\hline Gomphonema capitatum Ehrenberg & GomCa & 0 & 0 & 0 & 0 & $0-1$ \\
\hline Gomphonema clavatum Ehrenberg & GomCla & 0 & 0 & 0 & 0 & $0-1$ \\
\hline Gomphonema exilissimum Lange-Bertalot \& E. Reichardt & GomExi & 0 & 0 & 0 & 0 & $0-1$ \\
\hline Gomphonema minusculum Krasske & GomMis & 0 & $0-1$ & 0 & 0 & 0 \\
\hline Gomphonema minutum (C. Agardh) C. Agardh & GomMin & 0 & $0-1$ & 0 & 0 & 0 \\
\hline Gomphonema parvulum (Kützing) Kützing & GomPar & 0 & 0 & 0 & 0 & $0-1$ \\
\hline Halamphora veneta (Kützing) Levkov & $\mathrm{HaVe}$ & $0-1$ & 0 & 0 & 0 & 0 \\
\hline Hannaea arcus (Ehrenberg) R.M. Patrick & HanAr & 0 & 0 & 0 & 0 & $0-1$ \\
\hline Luticola goeppertiana (Bleisch) D.G. Mann & LuGoe & 0 & 0 & 0 & $0-1$ & 0 \\
\hline Mayamaea atomus (Kützing) Lange-Bertalot & MaAto & 0 & $0-1$ & 0 & 0 & 0 \\
\hline Navicula cincta (Ehrenberg) Ralfs & $\mathrm{NaCin}$ & 0 & 0 & 0 & 0 & $0-1$ \\
\hline Navicula cryptotenella Lange-Bertalot & NaCry & 0 & 0 & 0 & 0 & $0-1$ \\
\hline Navicula gregaria Donkin & NaGre & $0-1$ & 0 & 0 & 0 & $0-1$ \\
\hline Navicula salinicola Hustedt & $\mathrm{NaSal}$ & $0-1$ & 0 & 0 & 0 & 0 \\
\hline
\end{tabular}


Table 2. Species composition and relative abundance of diatoms in the studied springs.

\begin{tabular}{|c|c|c|c|c|c|c|}
\hline Taxon name & Abbreviations & $\begin{array}{c}\text { As } \\
\text { Burgas }\end{array}$ & Cuntis & Guitiriz & Pantón & Outariz \\
\hline Navicula tripunctata (O.F. Müller) Bory de Saint-Vincent & NaTri & $0-1$ & 0 & 0 & 0 & 0 \\
\hline Navicula veneta Kützing & NaVen & 0 & 0 & 0 & 0 & $0-1$ \\
\hline Nitzschia amphibia Grunow & NitAmp & $0-1$ & 0 & 0 & $1-2$ & $0-1$ \\
\hline Nitzschia bulnheimiana (Rabenhorst) H.L. Smith & NitBul & 0 & 0 & 0 & 0 & $0-1$ \\
\hline Nitzschia clausii Hantzsch & NitCla & 0 & 0 & 0 & $0-1$ & 0 \\
\hline Nitzschia fonticola (Grunow) Grunow & NitFon & 0 & 0 & 0 & $0-1$ & $0-1$ \\
\hline Nitzschia hantschiana Rabenhorst & NitHan & 0 & 0 & $0-1$ & 0 & 0 \\
\hline Nitzschia inconspicua Grunow & NitInc & 1 & $0-1$ & 0 & 0 & 0 \\
\hline Nitzschia palea (Kützing) W. Smith & $\mathrm{NitPa}$ & $0-1$ & 0 & 0 & 0 & $0-1$ \\
\hline Nitzschia palea var. debilis (Kützing) Grunow & NitPaD & 0 & $0-1$ & 0 & $1-2$ & 0 \\
\hline Nitzschia thermalis (Ehrenberg) Auerswald & NitTh & 0 & $0-1$ & 0 & 0 & 0 \\
\hline Nitzschia valdestriata Aleem \& Hustedt & NitVal & 0 & $0-1$ & 0 & 0 & 0 \\
\hline Pinnularia borealis Ehrenberg & PinBo & 0 & $0-1$ & 0 & 0 & 0 \\
\hline Pinnularia schoenfelderi Krammer & PinSch & 0 & $0-1$ & 0 & 0 & 0 \\
\hline Punctastriata sp. & Pun & 0 & 0 & 0 & 0 & $0-1$ \\
\hline Rhopalodia gibberula (Ehrenberg) Otto Müller & RhoGib & $1-3$ & 0 & 0 & 0 & 0 \\
\hline Rhopalodia operculata (C. Agardh) Håkanasson & RhoOp & 1 & 0 & 0 & 0 & 0 \\
\hline Sellaphora parapupula Lange-Bertalot & SePar & 0 & 0 & 0 & 0 & $0-1$ \\
\hline Sellaphora seminulum (Grunow) D.G.Mann & $\mathrm{SeSe}$ & $0-1$ & $0-1$ & 0 & $0-1$ & 0 \\
\hline Staurosira dubia Grunow & $\mathrm{StDu}$ & 0 & 0 & 0 & 0 & $0-1$ \\
\hline Staurosira venter (Ehrenberg) Cleve \& Moeller & StVen & $0-1$ & 0 & 0 & 0 & 0 \\
\hline Tabellaria flocculosa (Roth) Kützing & TaFlo & 0 & 0 & 0 & 0 & $0-1$ \\
\hline Ulnaria biceps (Kützing) Compère & UlBi & 0 & 0 & $0-1$ & $0-1$ & 0 \\
\hline Number of species in each spring & 19 & 20 & 7 & 11 & 40 & \\
\hline Number of genera & 11 & 12 & 4 & 6 & 18 & \\
\hline
\end{tabular}

Note: Relative abundance of diatoms: 0 - absence, 1 - (0-20)\% relative abundance, 2 - (21-40), 3 - (41-60); 4 - (61-80), $5-(81-100)$. 


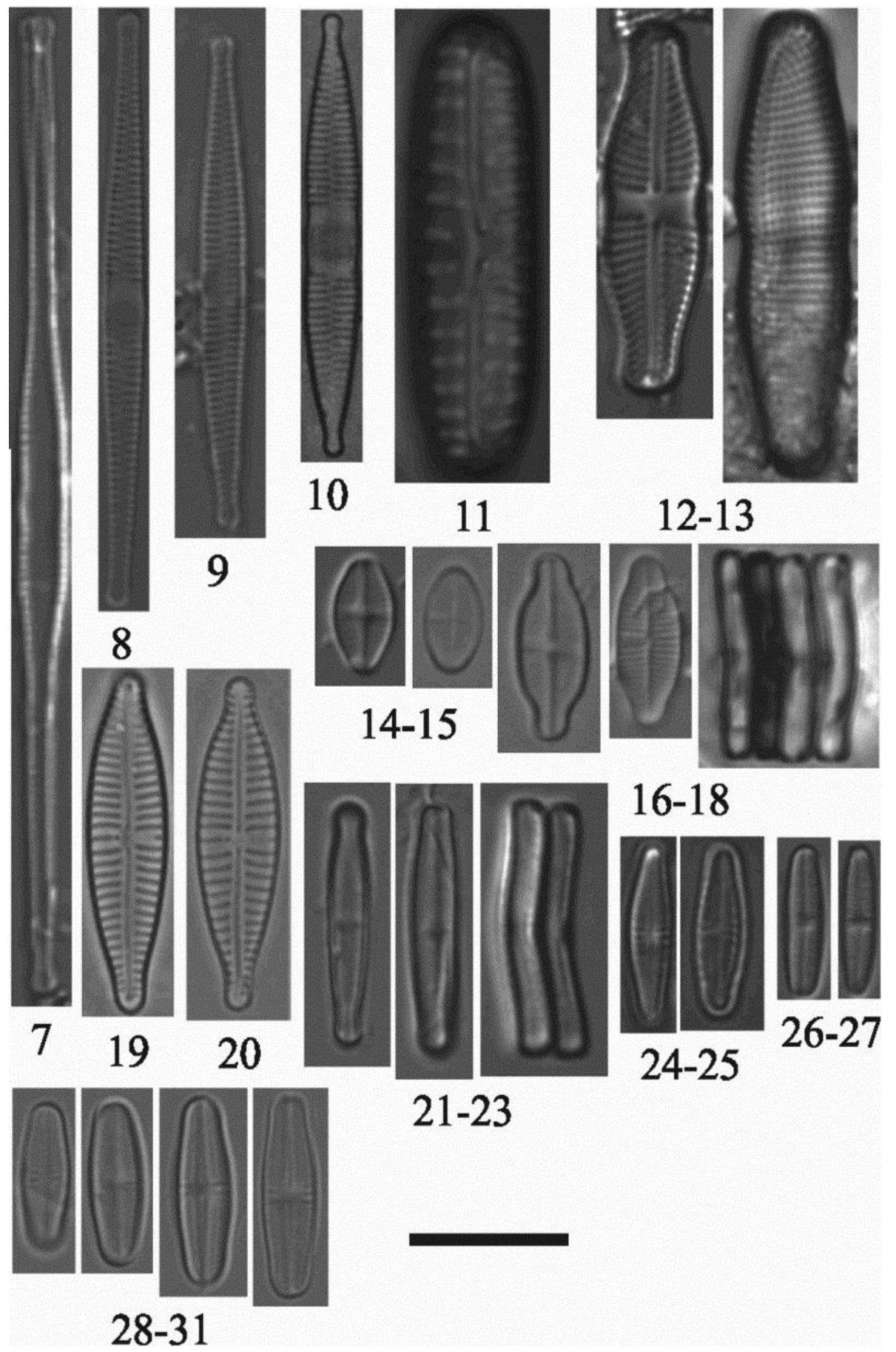

Figs 7-31. LM micrographs of the sampled material. Fig. 7. Fragilaria crotonensis. Fig. 8. Fragilaria pararumpens. Fig. 9. Fragilaria perminuta. Fig. 10. Fragilaria rumpens. Fig. 11. Pinnularia borealis. Figs 12, 13. Achnanthes coarctata (Fig. 12 - raphe valve, Fig. 13 - rapheless valve). Figs 14-18. Achnanthidium exiguum (Figs 14, 15 - raphe valve, Figs 16, 17 - rapheless valve, Fig. 18 - girdle view). Fig. 19. Gomphonema exilissimum. Fig. 20. Gomphonema parvulum. Figs 21-23. Achnanthidium caledonicum (Fig. 21 - raphe valve, Fig. 22 - rapheless valve, Fig. 23 - girdle view). Figs 24, 25. Achnanthidium minutissimum. Figs 26, 27. Achanthidium lineare. Figs 28-31. Achnanthidium saprophilum (Figs 28, 29 - rapheless valve, Figs 30, 31 - raphe valve). Scale bar $=10 \mu \mathrm{m}$. 


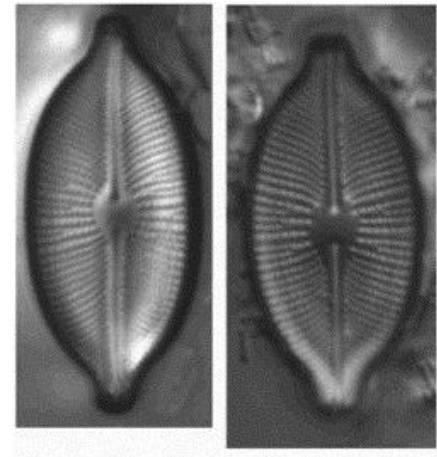

32-33

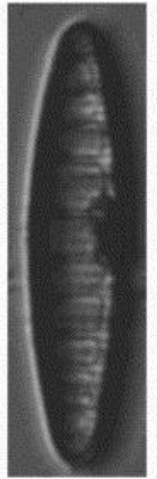

34-36
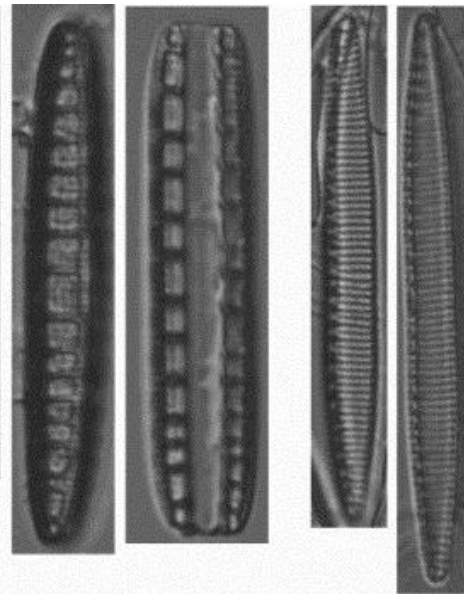

$37-38$

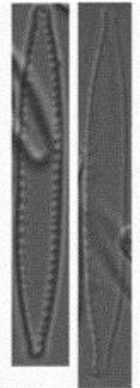

$39-40$

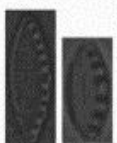

$41-42$
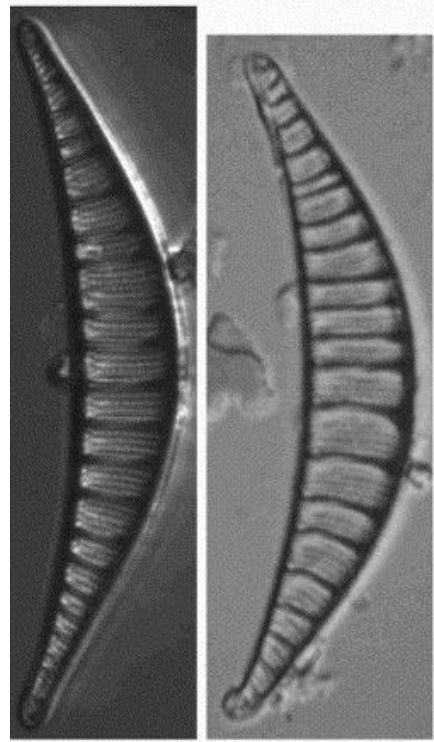

$43-45$
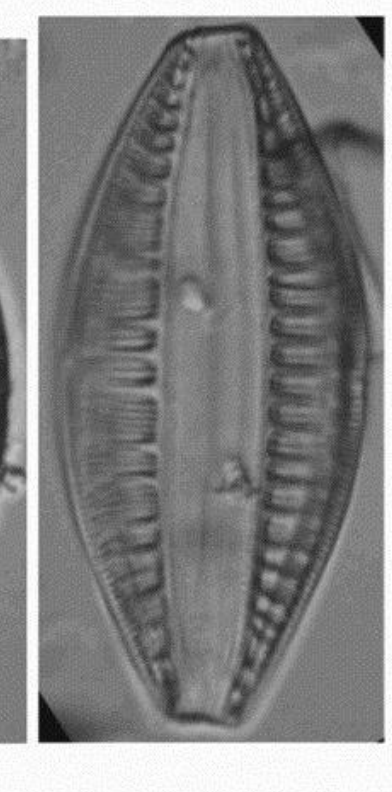

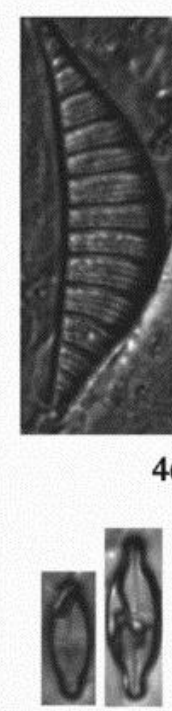

$48-49$

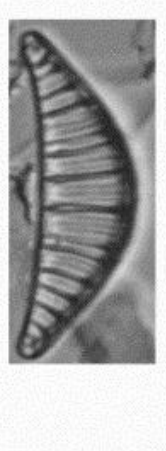

$46-47$

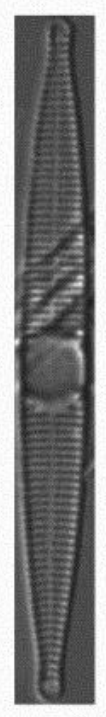

52
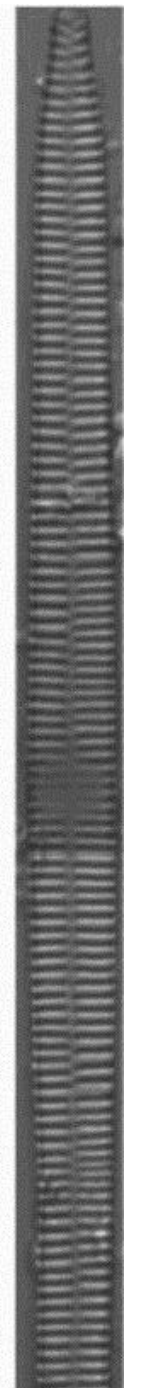

Figs 32-53. LM micrographs. Figs 32, 33. Cosmioneis pusilla. Figs 34-36. Denticula thermalis. Figs 37, 38. Nitzschia amphibia. Figs 39, 40. Nitzschia palea var. debilis. Figs 41, 42. Nitzschia inconspicua. Figs 43-45. Rhopalodia gibberula. (Fig. 45 - girdle view). Figs 46, 47. Rhopalodia operculata. Figs 48, 49. Achnanthes exigua var. elliptica. Figs 50, 51. Diadesmis contenta. Fig. 52. Ctenophora pulchella. Fig. 53. Fragilaria acus. Scale bar $=10 \mu \mathrm{m}$. 


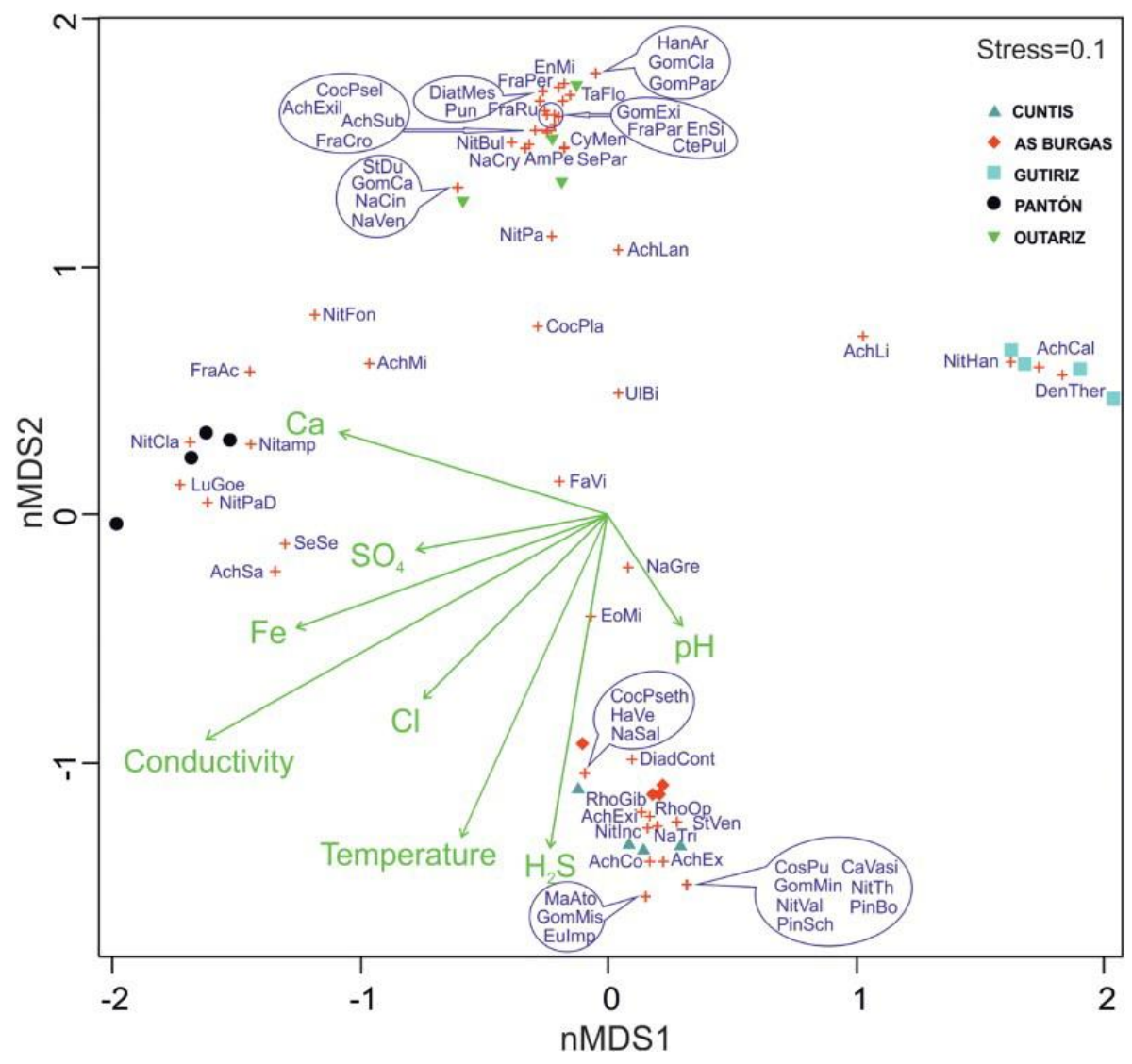

Fig. 54. The non-metric multidimensional scaling (nMDS) ordination diagram of the springs based on species composition. The eight environmental variables tested are shown as green arrows, with orientation and length indicating direction of greatest change and strength of correlation, respectively. Correlation data are shown in Table 3.

Nutrient levels (nitrate, nitrite, phosphate) were very low in the five springs, below detection limits $\left(\sim 0.01 \mathrm{mg} \mathrm{L}^{-1}\right)$. Trace element concentrations were compared with the United States Environmental Protection Agency guidelines (Usepa 1985 USEPA) for water quality criteria. Under these guidelines, critical concentrations of $\mathrm{Al}, \mathrm{Fe}$ and $\mathrm{Mn}$ ions for aquatic life are 87, 1000 and $1090 \mu \mathrm{g} \mathrm{L}^{-1}$, respectively, which, when exceeded, could harm aquatic organisms. None of the studied water samples had concentrations that exceeded these limits (Table 1).

After eliminating the redundant environmental variables, eight remained for further analysis by nMDS. Thus, conductivity, which measures total ionic concentration, summarized the information from the concentrations of $\mathrm{Li}, \mathrm{Na}, \mathrm{K}, \mathrm{HCO}_{3}, \mathrm{Ba}$ and $\mathrm{Al}$ ions. In addition, it was found that $\mathrm{SiO}_{2}$ concentration correlated with temperature.

\section{Diatom assemblages}

In total, 68 diatom taxa from 24 genera were found. In the hot springs, diatoms only occurred in the samples from shallow water or from damp ground located at or close to the springs, and at temperatures below $45^{\circ} \mathrm{C}$ (Table 1$)$. 
A taxonomic list of the recorded diatom species found with their relative abundances is presented in Table 2. Generic richness ranged from 4 to 18, whereas species richness ranged from 7 to 40. The maximum number of identified taxa (40) was found in Outariz and the minimum number (7) in Guitiriz. The most species-rich genera were Nitzschia Hassall and Achnanthidium Kützing with 10 and 8 species, respectively. The most common species were Achnanthidium exiguum (Grunow) Czarnecki (Figs 14-18) and Achnanthidium saprophilum (Kobayasi \& Mayama) Round \& L. Bukhtiyarova (Figs 28-31), which were found in four of the five springs. Seventy-two percent of the taxa were only found in one of the springs. Fourteen diatom species reached at least $10 \%$ relative abundance in at least one sample: Fragilaria crotonensis Kitton (Fig. 7), A. exiguum (Figs 14-18), Achnanthidium caledonicum (Lange-Bertalot) Lange-Bertalot (Figs 21-23), Achnanthidium minutissimum (Kützing) Czarnecki (Figs 24, 25), A. saprophilum (Figs 28-31), Cosmioneis pusilla (W. Smith) Mann \& Stickle (Figs 32, 33), Denticula thermalis Kützing (Figs 36-38), Nitzschia amphibia Grunow (Figs 37, 38), Nitzschia palea var. debilis (Kützing) Grunow (Figs 39, 40), Rhopalodia gibberula (Ehrenberg) O. Müller (Figs 43-45), Achnanthes exigua var. elliptica Hustedt (Figs 48, 49), Diadesmis contenta (Grunow) D.G. Mann (Figs 50, 51), Ctenophora pulchella (Ralfs ex Kützing) Williams \& Round (Fig. 52) and Fragilaria acus (Kützing) Lange-Bertalot (Fig. 53).

Outariz, Cuntis and As Burgas had the highest species diversity, whereas Pantón and Guitiriz had low-diversity assemblages. Outariz stands out, having 40 different taxa and an $H^{\prime}$ index of $2.01 \pm 0.56$. This contrasts with Guitiriz, a cold-water spring with moderate mineralization, in which only seven taxa were identified and the $\mathrm{H}^{\prime}$ index was lowest, $0.63 \pm 0.29$. The other springs had intermediate $H^{\prime}$ values: Pantón $1.55 \pm 0.35$, As Burgas $1.33 \pm 0.13$ and Cuntis $0.72 \pm 0.58$.

The nMDS ordination (Fig. 54) shows the differences in species composition among the five different springs forming four clusters, with Cuntis and As Burgas in the same cluster, indicating a greater degree of similarity between them. Following the removal of redundant environmental variables, eight variables were included in the analysis and fitted to the ordination space. Based on $R^{2}$-values (Table 3), conductivity, temperature and hydrogen sulphide had the strongest relationship with species composition.

Table 3. Relationships between the species ordination scores (nMDS) and the fitted environmental variables.

\begin{tabular}{lcccc}
\hline & nMDS1 & nMDS2 & $R^{2}$ & $p$ \\
\hline & & & & \\
Temperature & -0.97133 & -0.23773 & 0.331 & $0.049^{*}$ \\
$\mathrm{pH}$ & 0.56649 & -0.82407 & 0.0467 & 0.666 \\
$\mathrm{Conductivity}$ & -0.85003 & -0.52673 & 0.5339 & $0.003^{* *}$ \\
$\mathrm{Cl}$ & -0.99603 & -0.08905 & 0.2206 & 0.114 \\
$\mathrm{SO}_{4}$ & -0.53535 & -0.84463 & 0.0895 & 0.45 \\
$\mathrm{Ca}_{\mathrm{Fe}}$ & -0.11424 & -0.99345 & 0.2041 & 0.134 \\
$\mathrm{H}_{2} \mathrm{~S}$ & -0.94765 & 0.31932 & 0.2911 & $0.050^{*}$ \\
& -0.69844 & -0.71567 & 0.3251 & $0.044^{*}$ \\
\hline
\end{tabular}

Note: $(*): p<0.05 ;(* *): p<0.01$. 
The position of the diatom taxa in the nMDS ordination diagram showed that the species associated with lower conductivity and temperature were D. thermalis, A. caledonicum and Nitzschia hantzschiana Rabenhorst. These conditions occurred in Guitiriz samples. These species also appear to tolerate the presence of $\mathrm{H}_{2} \mathrm{~S}$, but at low levels. By contrast, species such as $R$. gibberula, Rhopalodia operculata (C.A. Agardh) Håkanasson, Pinnularia borealis Ehrenberg, Nitzschia thermalis (Ehrenberg) Auerswald, F. crotonensis, Navicula salinicola Hustedt and Achnanthes coarctata (Brébisson) Grunow were associated with more mineral-rich environments and higher temperatures.

\section{Discussion}

The Galician springs showed diatom populations that varied in terms of composition and abundance. The number of taxa found was higher in hot springs (63 in 3 sites) than in the cold springs (15 in 2 sites). This suggests that warm environments maintain a more diverse diatom population. However, 11 taxa were common to both hot and cold springs, demonstrating their great thermal amplitude. In the springs whose waters emerge at high temperatures, diatoms only occurred in samples collected where temperatures were below $45^{\circ} \mathrm{C}$. This is in accordance with the results of Smith et al. (2013) who studied the algal component of Hot Springs National Park (Arkansas, USA.), only observing diatoms in two springs at lower temperatures $\left(<40^{\circ} \mathrm{C}\right)$. Patrick et al. (1969) found that an average temperature of $34-38^{\circ} \mathrm{C}$ resulted in a shift of dominance in the algal flora from diatoms to cyanobacteria. However, there are examples of diatoms that occur at higher temperatures, as in hot springs from Kuril and Sakhalin Islands (Russia). At these locations, the largest number of diatom taxa was recorded in springs and reservoirs with water temperatures from $37^{\circ} \mathrm{C}$ to $60^{\circ} \mathrm{C}$ (Nikulina \& Kociolek 2011).

In the Galician springs, A. exiguum was the most common and abundant species. It was particularly abundant in the hot springs of Cuntis and As Burgas, with a relative abundance of a $90 \%$ in some samples. This species is considered typical of hot spring environments (Fairchild \& Sheridan 1974). It has a wide ecological amplitude and has been found in many different types of water, including industrial and other wastewater. Its occurrence has been recorded several times in high-temperature habitats (Quintela et al. 2013). In addition, this species is found in environments with moderate to elevated electrolyte content (Krammer \& Lange-Bertalot 1991b). Our results are in agreement with these observations; however, this species was scarce in the samples collected from Outariz whose temperature and conductivity were also high, but instead, it was also found in Guitiriz samples (cold spring). This is not surprising since Fairchild \& Sheridan (1974) found that the maximum and minimum temperatures at which this species grew were $44^{\circ} \mathrm{C}$ and $10^{\circ} \mathrm{C}$, respectively.

As in studies carried out on different springs in Europe (Delgado et al. 2013, Lai et al. 2016), Nitzschia was also the most represented genus in the Galician springs, by 10 species. Nitzschia is a widely distributed genus with a large number of species, several of which are ecologically important. They are very common (often the most abundant taxa) in different types of inland, coastal and marine waters (Trobajo et al. 2013). The predominant species in the Galician springs was N. amphibia, which was not only abundant (around 35\%) in the samples from the cold Pantón spring, but also was found (with lower abundance, <4\%) in the hot springs of As Burgas and Outariz. Although this species predominates in cold environments, for example in cold-water, low conductivity springs in eastern Spain (Aboal et al. 1998), it can occur in high-temperature environments (Mannino 2007). Owen et al. (2008) found that the optimum temperature for this species was $24.75^{\circ} \mathrm{C}$.

Another interesting genus found in three of our springs was Gomphonema Ehrenberg, whose species are relatively common in freshwater diatom communities, although most occurrences are in rivers and lakes, rarely in springs. As in other aquatic systems in Europe (Wojtal 2003), Gomphonema was represented in the Galician springs, although it was not very abundant. More 
Gomphonema species were found in the Outariz spring, but none were detected in the Guitiriz and Pantón samples. Gomphonema parvulum (Kützing) Kützing is widespread and very common in waters with a wide range of trophic characteristics (Abarca et al. 2014), but whether or not this species is ubiquitous and cosmopolitan remains controversial. In this study it was only found in the Outariz spring.

Achnanthidium minutissimum sensu lato was found in the outflow channels of Outariz and Pantón and was an important component of the diatom populations from these springs, although with a relative abundance below 20\%. It was also found in As Burgas, but with even lower $(<2 \%)$. Achnanthidium minutissimum was seventh in order of abundance in these springs, indicating that it is a typical species for these environments. Our data indicate that the temperature does not seem to be an important factor in its distribution and it is also widely distributed in springs in the Alps (Cantonati \& Lange-Bertalot 2010, Gesierich \& Kofler 2010, Mogna et al. 2015), on Majorca (Delgado et al. 2013), and in many alkaline springs elsewhere in Europe (Wojtal \& Sobczyk 2012 , Kollár et al. 2015, Luc \& Oosterlynck 2015). Its widespread occurrence throughout Europe contributes to the generally accepted idea that it is a ubiquitous taxon (Ector 2011). However, a complexity of forms has been attributed to this species and new taxa described from its varieties (Potapova \& Hamilton 2007, Van de Vijver \& Kopalová 2014). Nevertheless, moderate abundance of $A$. minutissimum in a river $(0-25 \%)$ has been considered as an indicator of no disturbance (Stevenson \& Bahls 1999). In fact, it was used with good results to characterize the quality of the waters of the Guadalquivir River (Martín et al. 2010) and for the assessment of Mediterranean rivers (Almeida et al. 2014). Similarly, A. minutissimum was also found in karst springs of Wyżyna Krakowsko-Czętochowska Upland in southern Poland (Wojtal \& Sobczyk 2012) where it was dominant in epilithic samples from springs located away from villages with lower specific conductivity. Mackay et al. (2012) consider this species to be sensitive to organic pollution and nutrient enrichment, which agrees with its presence in the unpolluted Galician springs. Therefore, all these data seem to support the idea that this species is a good indicator of good water quality and reinforces interest in this species as a bioindicator.

Although the diatom communities found in Galicia showed some similarities (especially the species of wide distribution) with other, more or less similar springs, diatom populations in the Galician springs differed in composition and abundance (Table 2). Thus, alpine springs with some similar characteristics to Guitiriz (cold water, low conductivity and slightly alkaline $\mathrm{pH}$ ) were dominated by A. minutissimum, Meridion circulare (Greville) C.A. Agardh var. circulare, Diatoma mesodon (Ehrenberg) Kiitzing, Denticula tenuis Kiitzing, Encyonema sublangebertalotii Lange-Bertalot \& M.Cantonati, Planothidium lanceolatum (Brébisson ex Kutzing) Lange-Bertalot, Achnanthidium pyrenaicum (Hustedt) Kobayasi or Achnanthidium dolomiticum M.Cantonati \& Lange-Bertalot (Cantonati \& Lange-Bertalot 2010). None of these species was found in Guitiriz, in which D. thermalis, A. caledonicum and Achnanthidium lineare W. Smith were the most abundant species. However, it is noteworthy that the alpine springs emerge through carbonate rocks and therefore have higher calcium and magnesium values of than those of Guitiriz (Galician springs mainly emerge on igneous and metamorphic rocks). Similarly, in cold springs on Majorca, also on calcareous substrata the diatom assemblages were characterised by A. minutissimum, A. pyrenaicum, Amphora pediculus (Kützing) Grunow ex A. Schmidt, Cymbella vulgata Krammer, Diploneis separanda Lange-Bertalot, Encyonopsis minuta Krammer \& Reichardt, Gomphonema lateripunctatum Reichardt \& Lange-Bertalot and Navicula cryptotenella Lange-Bertalot (Delgado et al. 2013). Only the cold Pantón spring, which had the highest calcium and magnesium values (Table 1), showed a certain similarity with those calcareous springs, owing to the presence of $A$. minutissimum, although the other species were different. Similarly, high-temperature Galician springs did not coincide with other sites within a similar temperature range. In the same way that the geothermal floras found elsewhere (Iceland, New Zealand and Kenya) vary in terms of composition, diversity and abundance (Owen et al. 2008), the Galician springs also vary. For example, of the most common diatoms found in Sicilian thermal-sulphur waters (A. pediculus, Cocconeis placentula Ehrenberg, Gomphonema minutum (C.A. Agardh) C.A. Agardh, Navicula cryptotenella Lange-Bertalot, Navicula tripunctata (O.F. Müller) Bory, $N$. amphibia, 
Rhoicosphenia abbreviata (C.A. Agardh) Lange-Bertalot, Gomphonema gracile Ehrenberg and Nitzschia commutata Grunow (Mannino 2007), only N. amphibia occurred in As Burgas and Outariz. Even D. contenta, abundant in the cold springs of Majorca, was also found in the samples from the three high-temperature Galician springs.

These results seem to indicate that it is difficult to establish a characteristic diatom flora for spring waters. In fact, none of the taxa were common to the five springs and only two (A. exiguum and $A$. saprophilum) were found in four springs. In addition, $73.5 \%$ of the taxa were only found in a single spring. It should be added that some of the taxa in these Galician springs were common, widely distributed species (probably habitat generalists) with broad ranges of tolerance to the major environmental variables.

However, there are other species for which the physical and chemical characteristics of the individual spring environment may be more decisive, controlling their distribution. Thus, different combinations of temperature and conductivity could explain the differences in the composition of diatom assemblages in the Galician springs. However, these factors are insufficient to explain the differences when the assemblages are compared with those from similar environments elsewhere. The Cuntis spring can be considered similar to other hot spring systems, in Iceland, New Zealand or Kenya (Owen et al. 2008), however its assemblages were different. One of the physical and chemical properties that characterize the Cuntis spring is its high $\mathrm{H}_{2} \mathrm{~S}$ content. Hydrogen sulphide content showed good correlation with the nMDS ordination and could be partially responsible for the differences observed. Hambrook et al. (1999) noted that important differences in the flora and fauna of regionally nearby springs in Ohio were due to the presence of $\mathrm{H}_{2} \mathrm{~S}$ in one of them. This toxic compound is considered an important factor in the distribution of the diatom populations because of their varying tolerance to it (Admiraal \& Peletier 1979). In fact, of the 20 species in Cuntis, 11 were found exclusively there (especially C. pusilla, A. coarctata and Mayamaea atomus (Kützing) Lange-Bertalot, Table 2). Of the remaining nine, N. palea var. debilis was also abundant in Pantón, another sulphur spring. It is also noteworthy that $N$. thermalis (found in Cuntis) was tolerant to a concentration of $\mathrm{H}_{2} \mathrm{~S}$ of $0.9 \mathrm{mM}$ in unialgal cultures in the laboratory (Admiraal \& Peletier 1979). Some of the species found in this spring coincide with those found in other springs of similar characteristics (temperature and presence of $\mathrm{H}_{2} \mathrm{~S}$ ), as are the thermal-sulphur waters of Fiume Caldo (Northwestern Sicily) (Mannino 2007), for example, G. minutum and Nitzschia inconspicua Grunow. However, as indicated above, the similarities are few, perhaps determined by the difference in conductivity; about five times greater in Fiume Caldo than in Cuntis. On the other hand, there are also differences in the diatom populations between Cuntis and a sulphidic spring in Slovenia (Eleršek \& Mulec 2014), although in this case the conductivities are very similar. However, these springs differ in temperature and $\mathrm{pH}$. Therefore, it is difficult to attribute a unique role to $\mathrm{H}_{2} \mathrm{~S}$ in determining species composition in Cuntis compared to other springs containing this compound. This is mainly due to the absence of data on $\mathrm{H}_{2} \mathrm{~S}$ content in springs, but the species found in Cuntis could be a useful for studying this type of environment. The lower diversity of diatoms in Cuntis could also be related to $\mathrm{H}_{2} \mathrm{~S}$ content compared with Outariz. Both springs had very similar temperatures and conductivities (Table 1), but species diversity was greater in Outariz. The species whose relative abundances differentiated the springs were A. exiguum, $F$. crotonensis, A. minutissimum and $C$. pulchella. Fragilaria crotonensis was abundant in the Outariz samples and was found in lakes that have a high sulphur content due to mining (Hamilton et al. 2015); however, it was not detected in the Cuntis samples. On the other hand, the presence (with relative abundance) of $A$. exiguum in the sulphidic Cuntis spring is an indicator of its wide distribution and resistance to stressors. 


\section{Conclusions}

Diatom assemblages found in the Galician springs showed great diversity. As in other springs, diatoms occurred at temperatures below $45^{\circ} \mathrm{C}$. A significant number of species were common to cold and hot springs. The environmental variables that had more influence on the distribution of diatoms were conductivity, temperature and $\mathrm{H}_{2} \mathrm{~S}$ content. This last variable could be important in determining the diatom composition in the sulphur spring of Cuntis. With respect to these variables it can be concluded: (1) A. exiguum and A. saprophilum are widely distributed; (2) $D$. thermalis, A. caledonicum and N. amphibia are common in low mineral content environments; (3) $R$. gibberula and $R$. operculata are abundant in mineral-rich environments with higher temperatures; and (4) A. exiguum, A. saprophilum, A. coarctata, A. exigua var. elliptica, $M$. atomus, E. implicata, G. minusculum, G. minutum and C. pusilla are tolerant to $\mathrm{H}_{2} \mathrm{~S}$.

\section{Acknowledgements}

M. Leira benefited from a FCT post-doc scholarship (SFRH/BPD/ 82103/2011). We thank Dr

Marina Potapova for the corrections and improvements made to the original manuscript.

\section{References}

Abarca N., Jahn R., Zimmermann J. \& Enke N. 2014. Does the cosmopolitan diatom Gomphonema parvulum (Kützing) Kützing have a biogeography? PLoS ONE 9: e86885.

Aboal M., Puig M.A. \& Prefast M. 1998. Diatom assemblages in springs in Castellón province, Eastern Spain. Algological Studies 90: 79-95.

Admiraal W. \& Peletier H. 1979. Sulphide tolerance of benthic diatoms in relation to their distribution in an estuary. British Phycological Journal 14: 185-196. 10.1080/00071617900650201

Almeida S.F., Elias C., Ferreira J., Tornés E., Puccinelli C., Delmas F., Dörflinger G., Urbanič G., Marcheggiani S., Rosebery J., Mancini L. \& Sabater S. 2014. Water quality assessment of rivers using diatom metrics across Mediterranean Europe: a methods intercalibration exercise. Science of the Total Environment 476-477: 768-776. doi: 10.1016/j.scitotenv.2013.11.144

APHA. 2005. Standard methods for examination of water and wastewater. 21 st ed. American Public Health Association, Washington, DC. 1200 pp.

Cantonati M. \& Lange-Bertalot H. 2010. Diatom biodiversity of springs in the Berchtesgaden National Park (north-eastern Alps, Germany), with the ecological and morphological characterization of two species new to science. Diatom Research 25: 251-280. 10.1080/0269249X.2010.9705849

Cantonati M., Füreder L., Gerecke R., Jüttner I. \& Cox E.J. 2012. Crenic habitats, hotspots for freshwater biodiversity conservation: toward an understanding of their ecology. Freshwater Science 31: 463-480. 10.1899/11-111.1

Comité European de Normalisation. 2003. Guidance standard for the routine sampling and pretreatment of benthic diatoms from rivers. Water Quality, Geneva.

Corral M.M. \& López J.A. 2010. Galicia: historia y evolución científica y técnica del conocimiento de las aguas minerales. Instituto Geológico y Minero de España, Madrid. 231 pp.

Delgado C., Ector L., Novais M., Blanco S., Hoffmann L. \& Pardo I. 2013. Epilithic diatoms of springs and spring-fed streams in Majorca Island (Spain) with the description of a new diatom species Cymbopleura margalefii sp. nov. Fottea 13: 87-104.

[CrossRef], [Web of Science $\left.{ }^{\circledR}\right]$

Delgado-Outeiriño I., Araujo-Nespereira P., Cid-Fernández J.A., Mejuto J.C., Martínez-Carballo E. \& Simal-Gándara J. 2009. Behaviour of thermal waters through granite rocks based on residence time and inorganic pattern. Journal of Hydrology 373: 329-336. doi:

10.1016/j.jhydrol.2009.04.028 
DeNicola D.M. 2000. A review of diatoms found in highly acidic environments. Hydrobiologia 433: 111-122. doi: 10.1023/A:1004066620172

Denys L. \& Oosterlynck P. 2015. Diatom assemblages of non-living substrates in petrifying Cratoneurion springs from lower Belgium. Fottea 15: 123-138. 10.5507/fot.2015.014

Ector L. 2011. $1^{\text {st }}$ European Workshop on Diatom Taxonomy ( ${ }^{\text {st }}$ EWDT). Algological Studies 136/137: 1-4. doi: 10.1127/1864-1318/2011/0136-0001

Eleršek T. \& Mulec J. 2014. The algal community at an ecocline of a cold sulphidic spring (Sovra artesian borehole, Slovenia). Environmental Earth Sciences 71: 5255-5261. doi: 10.1007/s12665-013-2928-4

Fairchild E. \& Sheridan R.P. 1974. A physiological investigation of the hot spring diatom, Achnanthes exigua Grün. Journal of Phycology 10: 1-4.

Gesierich D. \& Kofler W. 2010. Epilithic diatoms from rheocrene springs in the Eastern Alps (Vorarlberg, Austria). Diatom Research 25: 43-66. 10.1080/0269249X.2010.9705828

Hambrook J.A., Armitage B. \& Vis M. 1999. Algal and macroinvertebrate assemblages of selected Ohio Springs. Ohio Biological Survey Notes 2: 1-24.

Hamilton P.B., Lavoie I., Alpay S. \& Ponader K. 2015. Using diatom assemblages and sulfur in sediments to uncover the effects of historical mining on Lake Arnoux (Quebec, Canada): a retrospective of economic benefits vs. environmental debt. Frontiers in Ecology and Evolution 3: 99 . doi: 10.3389/fevo.2015.00099

Hofmann G., Werum M. \& Lange-Bertalot H. 2013. Diatomeen im Süßwasser-Benthos von Mitteleuropa. Bestimmungsflora Kieselalgen für die ökologische Praxis. Über 700 der häufigsten Arten und ihre Ökologie. Koeltz Scientific Books, Königstein. 908 pp.

Kelly M.G., Cazaubon A., Coring E., Dell’Uomo A., Ector L., Goldsmith B., Guasch H., Hürlimann J., Jarlman A., Kawecka B., Kwandrans J., Laugaste R., Lindstrøm E.-A., Leitao M., Marvan P., Padisák J., Pipp E., Prygiel J., Rott E., Sabater S., van Dam H. \& Vizinet J. 1998. Recommendations for the routine sampling of diatoms for water quality assessments in Europe. Journal of Applied Phycology 10: 215-224. 10.1023/A:1008033201227

Kilroy C., Biggs B.J.F. \& Vyverman W. 2007. Rules for macroorganisms applied to microorganisms: patterns of endemism in benthic freshwater diatoms. Oikos 116: 550-564. doi: 10.1111/j.0030-1299.2007.15447.x

Kindt R. \& Coe R. 2005. Tree diversity analysis. A manual and software for common statistical methods for ecological and biodiversity studies. World Agroforestry Centre (ICRAF), Nairobi.

Kollár J., Fránková M., Hašler P., Letáková M. \& Poulíčková A. 2015. Epiphytic diatoms in lotic and lentic waters - diversity and representation of species complexes. Fottea 15: 259-271. $10.5507 /$ fot.2015.022

Krammer K. \& Lange-Bertalot H. 1986. Bacillariophyceae. 1. Teil: Naviculaceae. In: Süßwasserflora von Mitteleuropa, Band 2/l (Ed. by H. Ettl, J. Gerloff, H. Heyning \& D. Mollenahuer), pp. 876. Gustav Fischer Verlag, Jena \& Stuttgart.

Krammer K. \& Lange-Bertalot H. 1988. Bacillariophyceae. 2. Teil: Bacillariaceae, Epithemiaceae, Surirellaceae. In: Süßwasserflora von Mitteleuropa, Band 2/2 (Ed. by H. Ettl, J. Gerloff, H. Heyning \& D. Mollenahuer), pp. 596. Gustav Fischer Verlag, Jena \& Stuttgar.

Krammer K. \& Lange-Bertalot H. 1991a. Bacillariophyceae. 3. Teil: Centrales, Fragilariaceae, Eunotiaceae. In: Süßwasserflora von Mitteleuropa, Band 2/3 (Ed. by H. Ettl, J. Gerloff, H. Heyning \& D. Mollenahuer), pp. 576. Gustav Fischer Verlag, Jena \& Stuttgar.

Krammer K. \& Lange-Bertalot H. 1991b. Bacillariophyceae. 4. Teil: Achnanthaceae, Kristische Ergänzungen zu Navicula (Lineolatae) und Gomphonema Gesamtliteraturverzeichnis Teil 1-4. In: Süßwasserflora von Mitteleuropa, Band 2/4 (Ed. by H. Ettl, J. Gerloff, H. Heyning \& D. Mollenahuer), pp. 436. Gustav Fischer Verlag, Jena \& Stuttgar.

Krammer K. \& Lange-Bertalot H. 2000. Bacillariophyceae. 2/5: English and French translation of the keys. In: Süßwasserflora von Mitteleuropa, Band 2/5 (Ed. by H. Ettl, J. Gerloff, H. Heyning \& D. Mollenahuer), pp. 576. Gustav Fischer Verlag, Jena \& Stuttgar.

Lai G.G., Padedda B.M., Wetzel C.E., Lugliè A., Sechi N. \& Ector L. 2016. Epilithic diatom assemblages and environmental quality of the Su Gologone karst spring (centraleastern Sardinia, Italy). Acta Botanica Croatica 75: 129-143. 
Lange-Bertalot H. 1993. 85 Neue Taxa und über 100 weitere neu definierte Taxa ergäenzend zur Süsswasserflora von Mitteleuropa. Bibliotheca Diatomologica, Band 27. A supplement to the above set, Vol. 2/1-4. Berlin. 454 pp.

Lange-Bertalot H. 1999. Neue Kombinationen von Taxa aus Achnanthes Bory (sensu lato). In: Iconographia Diatomologica. Annotated Diatom Micrographs (Ed. by H. Lange-Bertalot), pp. 276-289. Koeltz Scientific Books, Königstein.

Mackay A.W., Davidson T., Wolski P., Woodward S., Mazebedi R., Masamba W.R.L. \& Todd M. 2012. Diatom sensitivity to hydrological and nutrient variability in a subtropical, flood-pulse wetland. Ecohydrology 5: 491-502. doi: 10.1002/eco.242

Mannino A.M. 2007. Diatoms from thermal-sulphur waters of 'Fiume Caldo' (North-western Sicily). Cryptogamie Algology 28: 385-396.

Martín G., Toja J., Sala S., Fernández M.R., Reyes I. \& Casco M. 2010. Application of diatom biotic indices in the Guadalquivir River Basin, a Mediterranean basin. Which one is the most appropriated? Environmental Monitoring and Assessment 170: 519-534. 10.1007/s10661-0091254-5

Mogna M., Cantonati M., Andreucci F., Angeli N., Berta G. \& Miserere L. 2015. Diatom communities and vegetation of springs in the south-western Alps. Acta Botanica Croatica 74: 265-285. 10.1515/botcro-2015-0024

Nikulina T.V. \& Kociolek J.P. 2011. Diatoms from Hot Springs from Kuril and Sakhalin Islands (Far East, Russia). In: The Diatom World (Ed. by J. Seckbach \& P. Kociolek), pp. 333-363. Springer, Dordrecht.

Noguerol A. 1984. Cianofíceas termófilas de (Ourense). Anales de Biología. Secretariado de publicaciones. Universidad de Murcia. 2: 127-133.

Owen R.B., Renaut R.W. \& Jones B. 2008. Geothermal diatoms: a comparative study of floras in hot spring systems of Iceland, New Zealand, and Kenya. Hydrobiologia 610: 175-192. doi: 10.1007/s10750-008-9432-y

Patrick R., Crum B. \& Coles J. 1969. Temperature and manganese as determining factors in the presence of diatom or blue-green algal floras in streams. Proceedings of the National Academy of Sciences of the USA 64: 472-478.

Potapova M. \& Hamilton P.B. 2007. Morphological and ecological variation within the Achnanthidium minutissimum (Bacillariophyceae) species complex. Journal of Phycology 43: 561-575.

Quintela A., Almeida S.F.P., Terroso D., da Silva E.F., Forjaz V. \& Rocha F. 2013. Diatom assemblages of thermal and mineral waters from volcanic environments in São Miguel Island, Azores. Diatom Research 28: 407-417. doi: 10.1080/0269249X.2013.822833

$\mathrm{R}$ Core Team. 2016. $R$ : a language and environment for statistical computing. R Foundation for Statistical Computing, Vienna. Available from: https://www.R-project.org/

Shannon C.E. \& Weaver V. 1963. The mathematical theory of communication. University of Illinios Press, Urbana, IL. 144 pp.

Smith T.E., Manoylov K.M. \& Packard A. 2013. Algal extremophile community persistence from hot springs National Park (Arkansas, U.S.A.). International Journal on Algae 15: 65-76. 10.1615/InterJAlgae.v15.i1.50

Stevenson R.J. \& Bahls L.L. 1999. Periphyton protocols. In: Rapid Bioassessment Protocols for Use in Wadeable Streams and Rivers: Periphyton, Benthic Macroinvertebrates and Fish (Ed. by M.T. Barbour, J. Gerritsen \& B.D. Snyder), pp. 1-22. Environmental Protection Agency, Washington, DC.

Trobajo R., Rovira L., Ector L., Wetzel C.E., Kelly M. \& Mann D.G. 2013. Morphology and identity of some ecologically important small Nitzschia species. Diatom Research 28: 37-59.

USEPA. 1985. Guidelines for deriving numerical national water quality criteria for the protection of aquatic organisms and their uses. National Technical Information Service. United States Environmental Protection Agency, Springfield, VA. 59 pp.

Van de Vijver B. \& Kopalová K. 2014. Four Achnanthidium species (Bacillariophyta) formerly identified as Achnanthidium minutissimum from the Antarctic Region. European Journal of Taxonomy 79: 1-19. 
Wojtal A. 2003. Diatoms of the genus Gomphonema Ehr. (Bacillariophyceae) from a karstic stream in the Krakowsko-Częstochowska upland. Acta Societatis Botanicorum Poloniae 72: 213-220.

Wojtal A. \& Sobczyk Ł. 2012. The influence of substrates and physicochemical factors on the composition of diatom assemblages in karst springs and their applicability in water-quality assessment. Hydrobiologia 695: 97-108. doi: 10.1007/s10750-012-1203-0

Xunta de Galicia 1995. Las aguas minerales de Galicia. Consellería de Industria e Comercio. Xunta de Galicia, Santiago de Compostela. 205 pp. 